\title{
Evaporites in Albania and their impact on the thrusting processes
}

\author{
Telo Velaj \\ Institute of Geological Research, Tirana, Albania \\ E-mail:ispgj@ingeol.tirana.al ispgj@ingeol.tirana.al
}

(Received 5 August 1999; accepted 2 June 2000)

\begin{abstract}
The Upper Triassic evaporites are widespread in Albania, Greece and Montenegro (mainly on External zones). They belong to the Alpine orogene system of the Periadriatic chains. The Upper Triassic age of the evaporites up to date has been determined by spore-pollen examinations only for the Ionian zone. For the Kruja and Korabi zones there are no determinations. All the evaporite outcrops in the Ionian zone (Dumrea's, Glina's Zavrohona's, Delvina's, PicarKardhiqi's, Bashaj's, Xara's, Filat's etc) result from eruption under the effect of thrust tectonics. The wells drilled both in Albania and in Greece have shown a wide extension of the evaporites on the surface. The evaporite outcrops are absent in the Kruja zone in Albania. Evaporitic diapirs have extruded through the thrusting faults of the zones, belts and units. In some cases they have flowed nearly vertically in the centre of the carbonate anticlinal structures. The External zones resulted from the orogenic activity over which evaporites have played a large role with the form of folds and thrust belts. Especially, they have helped the thrusting process of the structural belts and tectonic zones.
\end{abstract}

Key words: Evaporites, Diapirs, Overthrust, Albania.

\section{INTRODUCTION}

Surface and subsurface geological data show that Upper Triassic evaporites are located both in the Dinarides-Albanides-Helenides active margin and in the Adriatic platform. They constitute the substratum of the Albanide foreland fold and thrust belt and are a perfect detachment level (Fig. 1).

Hence, evaporites affect the regional structural model having an impact on the thrusting processes and relations between the orogen and the platform.

\section{LITHOLOGY AND STRATIGRAPHY OF THE EVAPORITES}

The evaporites in Albania generally consist of intercalations of gypsum, anhydrides, salts, dolomitic limestones, multicoloured clays and breccias. Volcanic rocks (Dumre, Picar-Kardhiq), quartz bipyramidal minerals (Dumre, Picar - Kardhiq, Delvine, Gline, Xare - Mursi, Bashaj, Janicat, Korab) and amphibolitic rocks (Picar, Bashaj) are encountered locally.

Salts are widespread in the middle Ionian subzone (the Kurveleshi anticlinal belt), whereas in the western and eastern zones or subzones of the Albanides, a gypsum and anhydritic facies predominates. Here, the salts are almost absent. The stratigraphic column of the
Ionian zone is composed of Upper Triassic evaporites, Upper Triassic to Eocene carbonates, Oligocene flysch, lower Miocene to Seravallian premolasse and Tortonian to Pliocene molasse.

The Late Triassic age of the evaporites was determined by spore-pollen examinations whereby the presence of Camerosporites, Patinosporites, Verricosisporites, Ovalipolis sp., Zonalisporotes etc. was confirmed. The evaporites of the western border of the Ionian zone at the contact with the Apulian platform are dated as Early Jurassic by the presence of Dacrydium and absence of Cicatricasporites (Muhameti et al, 1974).

The age of the Korabi zone evaporites can only be inferred from the stratigraphy of the surrounding rocks. The location of the evaporites in the Kruja zone can only be assumed as their presence has not been proven yet.

\section{SURFACE AND SUBSURFACE OCCURRENCE OF THE EVAPORITES}

Evaporites are widespread in the Periadriatic continental orogen. Surface and subsurface locations include those in the Ionian zone (Albania, Greece), in the Kruja zone, (Dalmatia-Montenegro), in the Umbria 


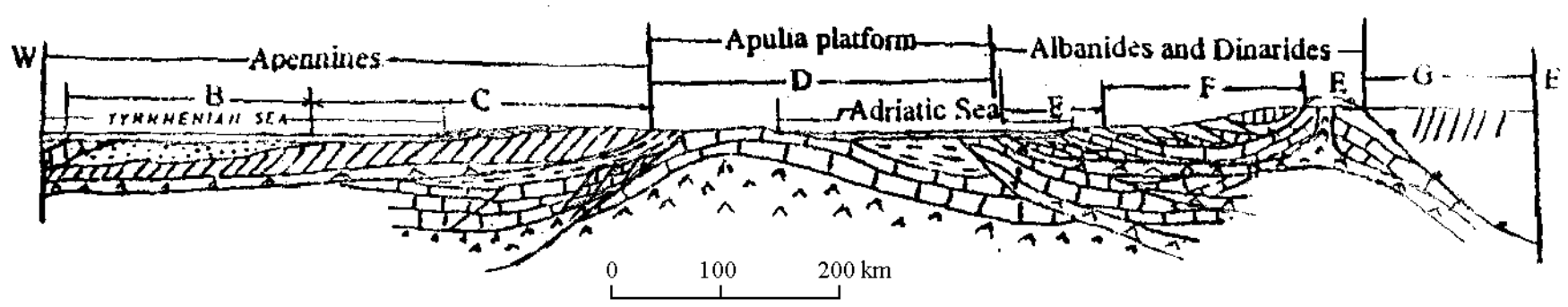

\title{
[n Evaporite sequences UIIIIIIII Eugeosinclinat sequences QZZZZ Mesozoic deposits in the
}

\author{
Apennines Tertiary deposits in the Aperinines Mesozoic and Tertiary depusits in the \\ Albanides. $=E$ Molass siduentus in the PAD.
}

FIG. 1. Schematic cross-section across Albanides-Dinarides-Apennines. B - Toscana cover in the Apennines; C The Umbro-Marchegian zone; D - The Apulia Platform; E - External Albanides (Ionian and Kruja zones); E Tectonic window of the External Albanides within the Internal Albanides; F - The Internal Albanides; G - Vardar and Serbo-Macedonia zones].

- Marche(Italy), and in the Apulia zone. Evaporite outcrops are also encountered in the Korabi zone (Albania) and in Toscana (Italy) (Figs. 2, 3).

All the evaporite outcrops result from eruption under the effect of thrust tectonics. They occur in depression (low lithostatic pressure) and tectonically active areas where longitudinal faults intersect transversal ones. These faults occurred during the rifting stage and were inverted during the compressional stage. The evaporites of the Ionian zone outcrop both along the regional tectonic faults (e.g. in Dumrea, Glina, Zavrahona, Palasa etc.) and local structures (e. g. in Delvina, Bashaj, Fterra etc.) (Fig. 3).

The Dumrea evaporites represent a salt dome with a surface area of $210 \mathrm{~km}^{2}$, which outcrop in an elliptic form with axes of $20 \times 10 \mathrm{~km}$. In depth they have the form of a diapir with a thickness of $6.1 \mathrm{~km}$ and a westward overthrust displacement of over 20-30 km. Its volume is over $1500 \mathrm{~km}^{3}$. Prospective carbonate structures for hydrocarbon exploration are evidenced under the evaporites through seismic studies carried out in this region, (Velaj, 1983) (Figs. 4, 5).

The Delvina evaporites have an area of $18 \times 0.2-3 \mathrm{~km}$ and thickness of $0.5-3-4 \mathrm{~km}$. They present a westward thrusting of 7-8 km (Fig. 6). An anticlinal structure has also been discovered under the Delvina diapir, which is an oil-condensate field (Velaj 1985).

The Bashaj, Fterra, Glina and Palasa evaporites have small dimensions $(0.2-5 \mathrm{~km}, 10-100 \mathrm{~m})$. They also occur as a vertical diapir like the Navarica's in the centre of the Krongji-Livine anticline, the Xara's in the Bogaz's and the Picar-Kardhiqi's in the Kurvelesh's unit (Fig. 3).

The evaporites of Picari-Kardhiqi present a considerable spread $(14 \times 0.5-3.5 \mathrm{~km})$, they overthrust southward (Fig. 7) and hide structures of great interest for oil exploration. The thickness of the diapiric body is $3-4 \mathrm{~km}$.

The Xara evaporites have an area of $7 \mathrm{~km}, 1.5-3 \mathrm{~km}$ and thickness of 4-6 km (Fig. 8). The outcrops of Navarica and Janicati present a very small spread. It should also be stressed that the Picar - Kardhiqi and Bashaj - Vermik evaporites are associated with amphibolite-rich igneous rocks.

The wells drilled both in Albania and Greece have shown a wide extent of the evaporites in the subsurface (Fig. 8). Some wells drilled on the carbonate anticlines have encountered evaporitic strata (e.g. the wells: Aitolikon-1, Astakos - 1, etc.). The well Filiati -1 after a diapir penetration of $3700 \mathrm{~m}$ encountered young deposits (Serravalian) thus showing an overthrusting of the orogen onto the platform (Jenkins 1972) (Fig. 8).

Evaporite outcrops are almost absent in the Kruja zone (Gavrovo zone in Greece). Some small gypsum outcrops occur at the contact with Lower Oligocene shales in the southern flank of the Letani structure. Sulphurous water has been encountered in the southern part of the Tomorr - Melesin - Postenan- Sarandaporo structural alignment both in Albania and Greece. Hot and curative water has been encountered in Elbasan (Llixha and wells Elbasan -11, Kozan - 8) and in Ishmi (well Ishmi-1). These subsurface waters indicate the presence of evaporites in depth.

The lack of surface and subsurface information of the Krasta-Cukali zone gives no constraints on the evaporite presence here. The evaporite presence can only be assumed from some small events such as sulphur water in Strikcan (Peshkopi), native sulphur reservoir in Kercisht etc. The latter belongs to the flysch tongue 
of the Krasta zone and suggests the eastward continuation of the evaporites underneath the Krasta zone (Melo et al. 1991, Velaj et al. 1991) (Fig. 9).

In the Dalmato-Montenegro zone of the Dinarides, the evaporites outcrop in the Vis island, where they form a diapir root along with basaltic-andesitic intrusions in the Cretaceous carbonate anticline. The wells drilled along the Dalmatian coast have shown a wide extension of the evaporites in the subsurface (Herak, 1973, Dragasevic, 1983) (Figs. 1 - 10).
In the Apennines, the evaporites outcrop along the tectonic fault planes of the structural units with an eastern vergence of the Umbro-Marchegian , Toscana and Calabri zones. Also, the wells (e.g. Trev -1, Burano -1, Antrodoco, etc.) drilled in these zones attest to the subsurface presence of evaporites (Martinis and Pieri, 1963) (Fig. 1).

In the Apulia platform the evaporites outcrop only in the Lesina diapir (the Gargano Peninsula) which represents a nearly vertical eruption and consists of gypsum,

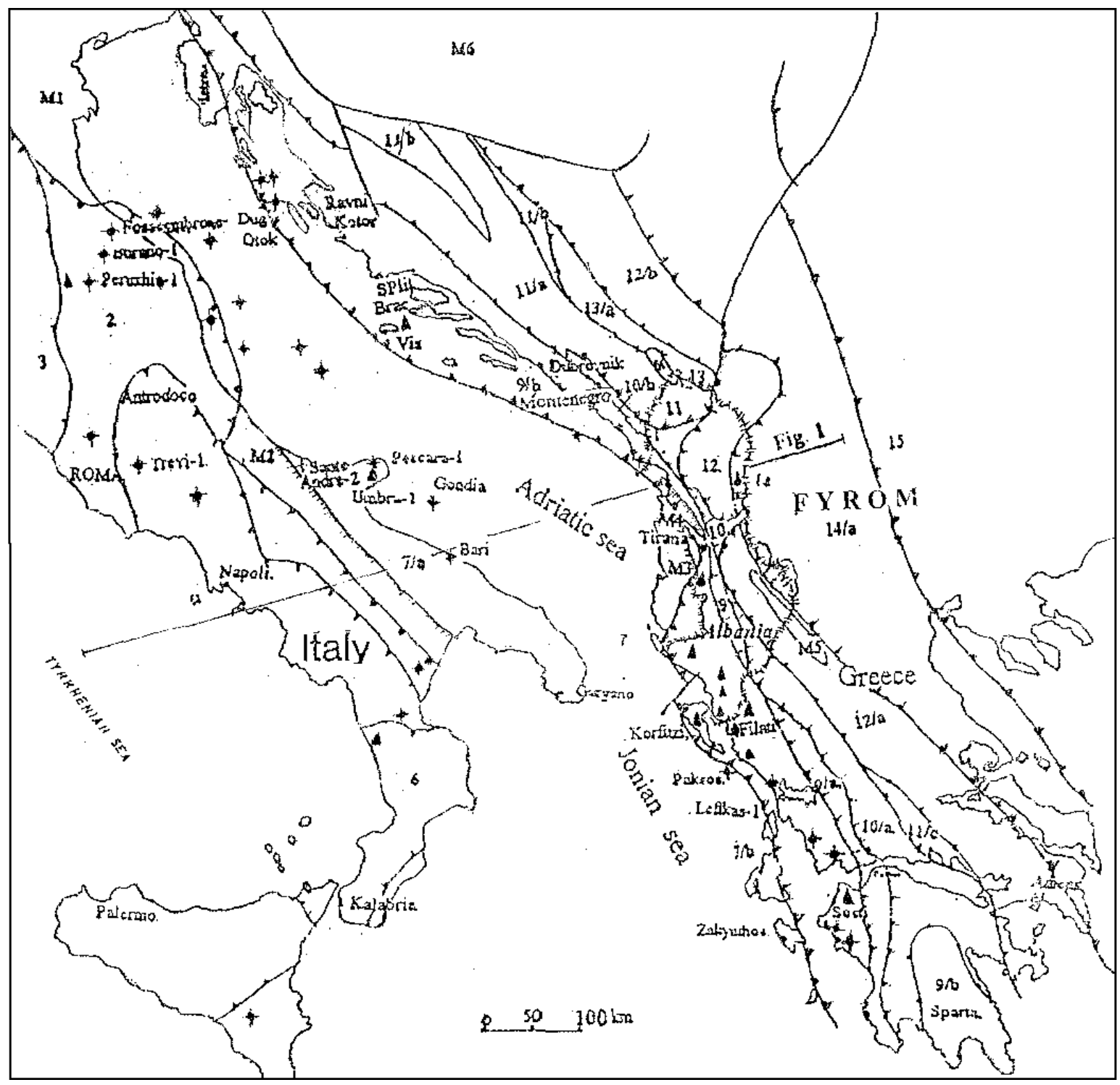

FIG. 2. Regional tectonic settings of the Albanides, Helenides, Dunarides and Apennines. + - Wells which have encountered evaporites; $>$ - Evaporites sequences; 1 - The eastern Liguri and Toscana allochthonous zones; 2 Umbro-Marche zone; 3 - Toscana autichthony; 4 - Lazano-Campano zone; 5 - Lgonegro-Molizane zone; 6 - Calabria crystaline massive; 7 - Sazaru zone (7a - Apulia platform; $\mathbf{7 b}$ - Paxos zone); 8 - Ionian zone; 9 - Kruja zone (9a Dalmatia zone; 9b - Gavrova zone); 10 - Krasta zone (10a - Pindi zone; 10b - Budva zone); 11 - Albanian Alps (11a - Karst zone; 11b - Bosnja zone; 11c - Pamas zone); 12 - Mirdita zone (12a - Subpelagonian zone; 12b - Golia zone); 13 - Gashi zone (13a - Durmitor zone); 14 - Korabi zone (14a - Pelagonian zone); 15 - Vardar zone; M1 Padan depression; M2 - Molise depression; M3 - Peri Ariatik depression (PAD); M4 - Tirana depression: M5 Korca depression; M6 - Panonian depression. 


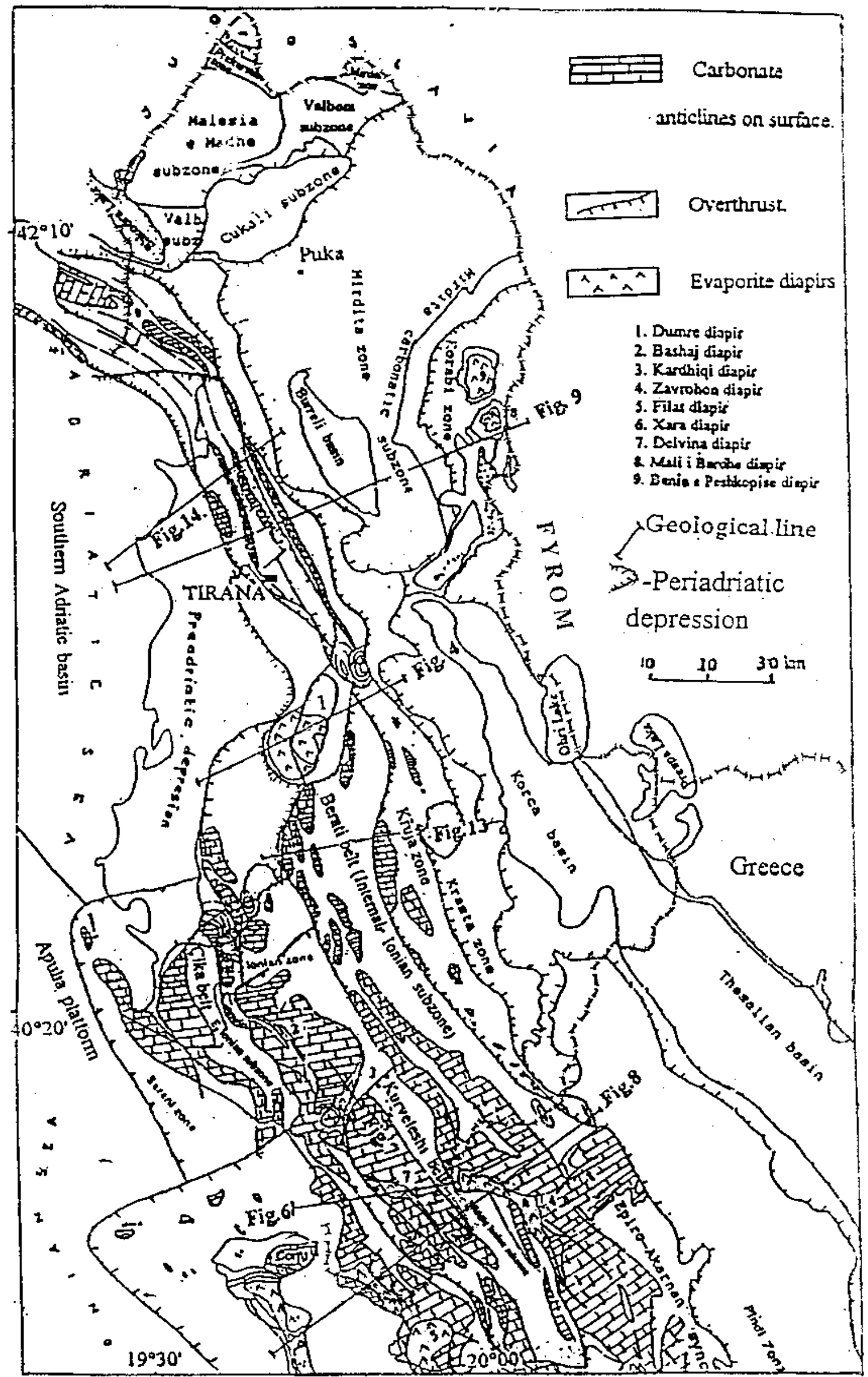

FIG. 3. Tectonic map of Albanides and carbonate structures in the Ionian and Kruja zones. 


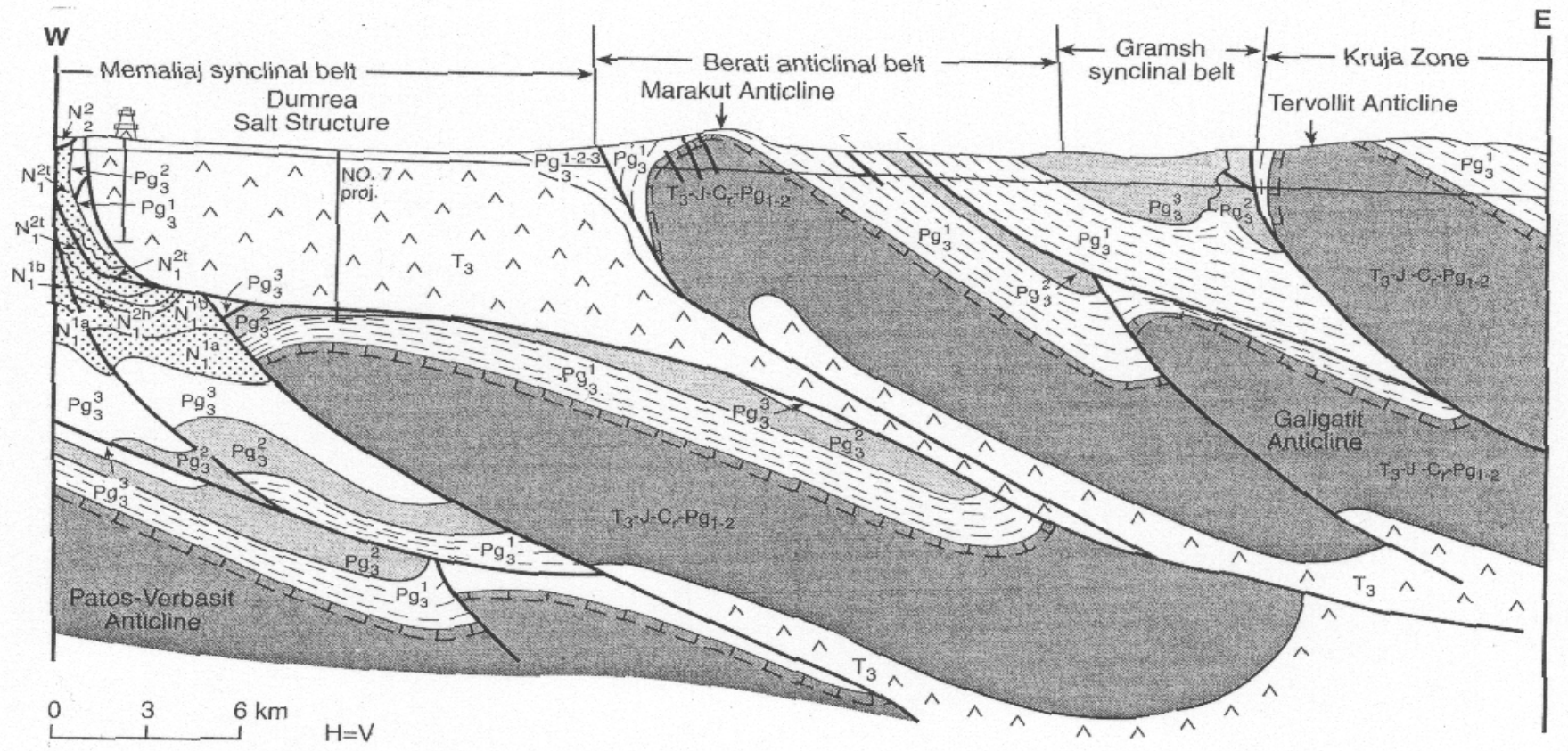

FIG. 4. Schematic cross section of the Dumrea diapir

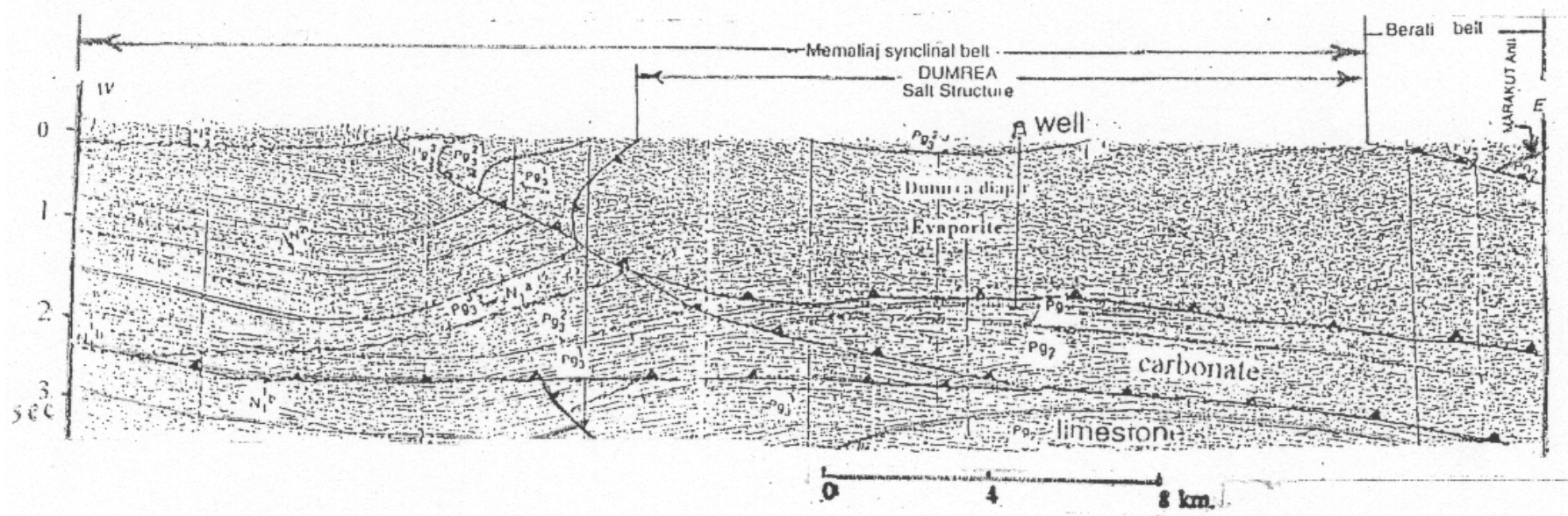

FIG. 5. Cross section throught the Dumrea diapir

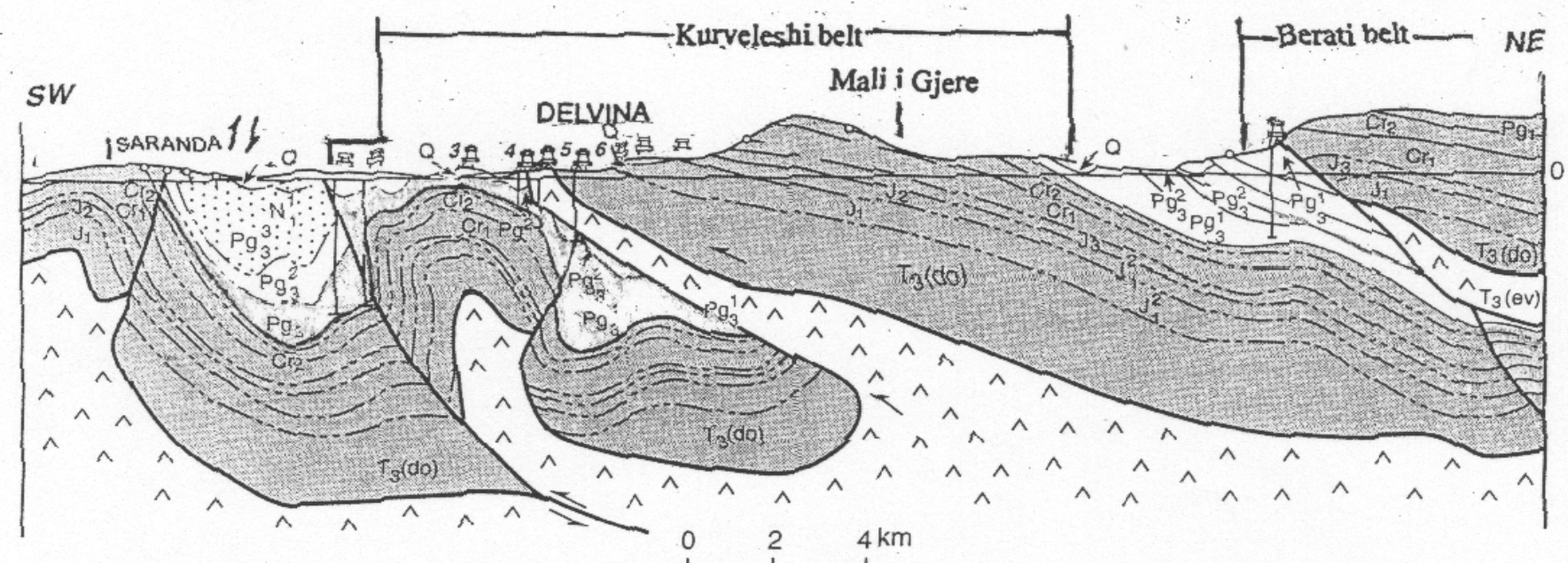

FIG. 6. Schematic geological cross-section across the Delvina diapir 
dolomitic limestone and volcanic rocks. Many wells drilled there, after penetrating the Mesozoic carbonate section, have remained suspended in the evaporites section although they are very deep (down to $6500 \mathrm{~m}$ ), (Marco, 1975).

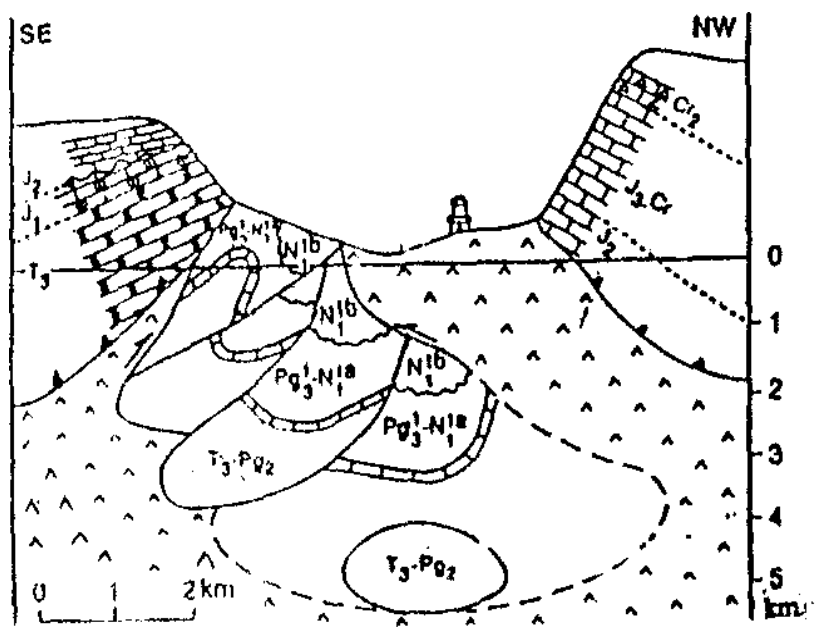

FIG. 7. Schematic geological cross-section across the Kardhiqi diapir

The diapir influence in this platform is still unclear. The fact that on the Apulia platform extends the Periadriatic depression (P A D) with a thickness of 6-8 $\mathrm{km}$ and that the evaporitic formation occurs at a depth of 5-12 km creates conditions for its "flow" toward the depressive sector thus favouring the blocky construction model.

In the Korabi (Pelagonian) zone the evaporites outcrop at two tectonic windows with a cupola shape (the diapirs of Mali i Bardhe and Banjat e Peshkopise). They continue southwards with the diapir of Dibra e Madhe (FYROM) (Figs. 11, 12). Mali i Bardhe window has dimensions of $11 \times 6 \mathrm{~km}$. The Banja e Peshkopise window has dimensions of $9 \times 6 \mathrm{~km}$. They are composed of gypsum and anhydride. The cupolas extend meridionally and represent tectonic windows within the allochthonous Korabi zone. There, the evaporites are in contact with the Krasta Eocene flysch and with the Upper Cenomanian rudistic carbonates.

The evaporites contact also with the Mesozoic and Palaeozoic deposits of the Korabi zone. In depth the evaporites are expected to have a wider spreading. They must be present underneath the cupola structure of the Korabi zone north of the Veleshica stream (Melo et al., 1991). These facts suggest that the Korabi evaporites might belong to the Kruja (or to the Krasta ?) zone.

\section{TECTONIC SETTING OF THE EVAPORITES}

The evaporites in Albania are encountered in three tectonic settings:

a. Evaporitic diapirs that have erupted through regional fault planes with a $20-30 \mathrm{~km}$ westward vergeance and occur at the boundary of tectonic zones or belts.

1. In the western front of the Berati belt (the external subzone of the Ionian zone) the regional fault slip is about 20-30 km (Fig. 8). This overthrust is realised through a big diapiric mass which outcrops there, where depressional sectors occur such as the Dumrea diapir, of Zavrahona (Velaj 1995, Velaj et al., 1995) (Fig. 3).

The evaporites have helped the thrusting process westwards. Sufficient surface and subsurface data (mostly seismic) suggest that carbonate structures might occur underneath the fault plane. (e. g. the northward continuation of the Kasidhiaris - Kurenton - Thesprotikon line under the Berati anticlinal belt - the Zavrohona diapir - and Dumrea structure) (Figs. 4, 5, 13).

Hidden diapirs developed along the fault planes and have affected the geological model increasing the structure dimensions, forming new highs of horst type in the centre of the synclines (the Timfeu massive) (Bornovas et al., 1983) (Fig. 8).

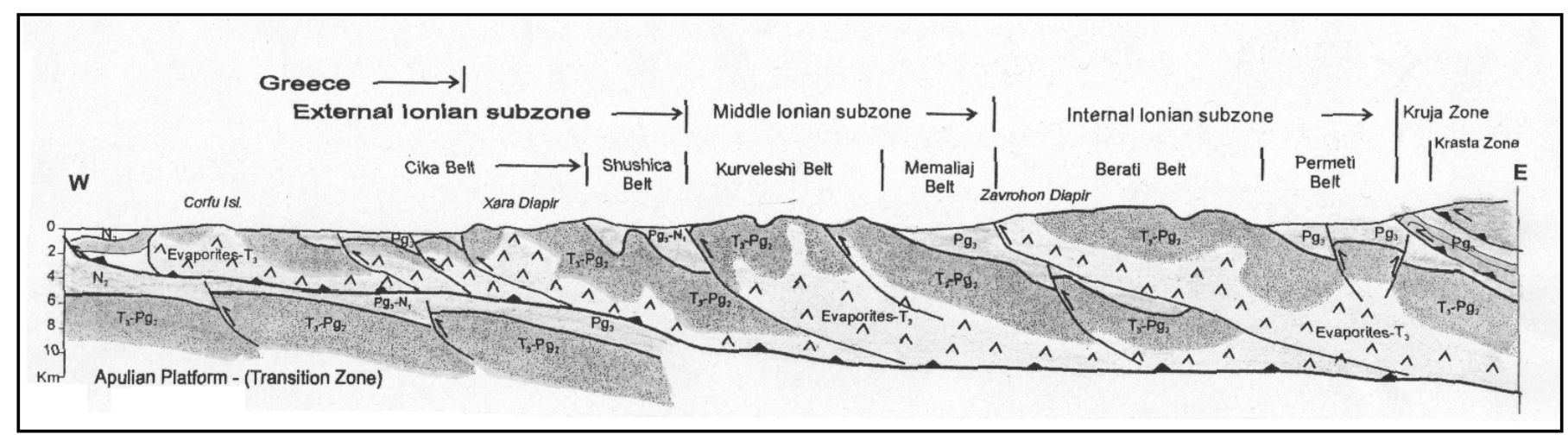

FIG. 8. Schematic geological cross-section in the Ionian zone 


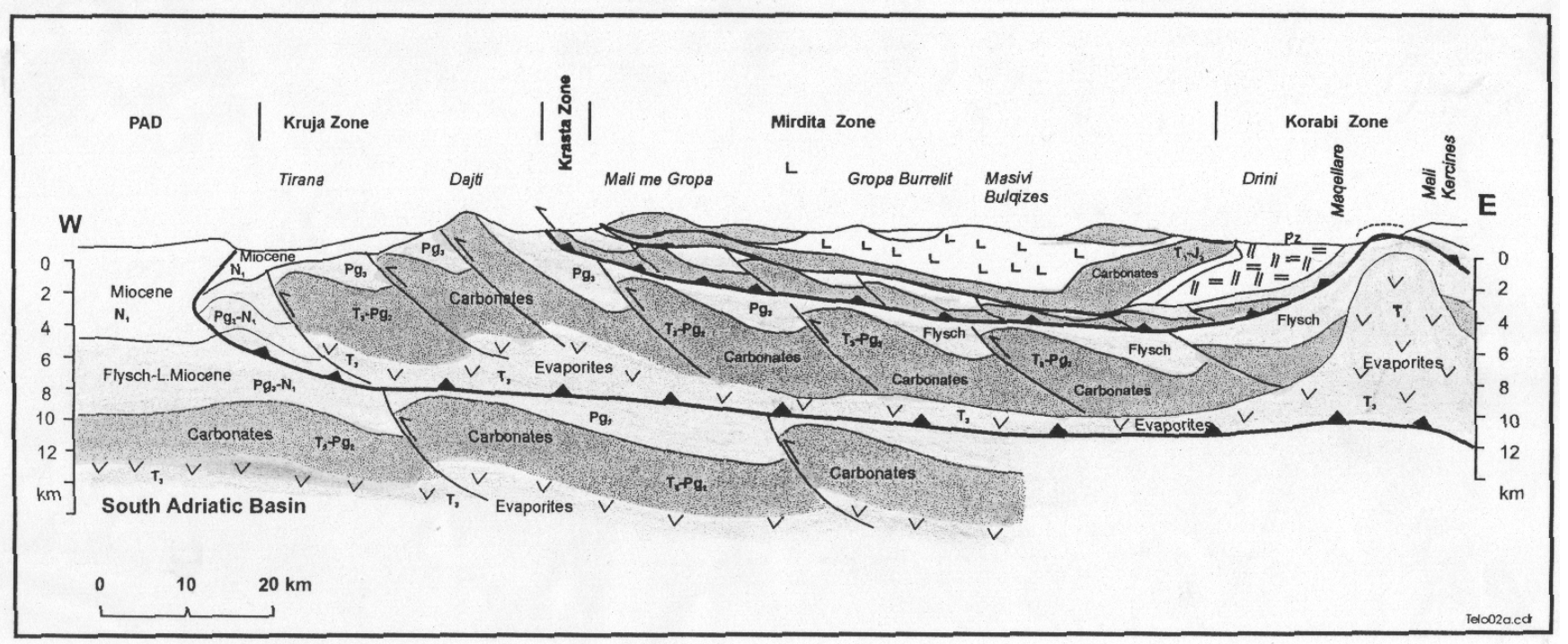

FIG. 9. Schematic geological cross-section through the Albanides and their relation with the South Adriatic basin

2. In the western front of the Cika anticlinal belt (external subzone of the Ionian zone) a regional overthrusting fault exists, which in its northern part deviates eastnorthward, thus cutting off the Cika belt, the Kurveleshi belt and, farther north, it joins the Berati belt front. In this sector, that thrust fault is transformed into a strike-slip thus indicating that the Ionian zone may continue northwards of Dumrea (Fig. 3). Through this fault and the diapiric body, the orogen overrides the Apulian platform (Fig. 8) with an amplitude of 50-100 $\mathrm{km}$, hiding underneath the transitive zone (from platform to orogen) with a possibility of the presence of the prospective works. The surface appearances of the diapir of this fault occur on the territory of Greece whereas in Albania they are absent (Bornovas et al., 1995, IFP-IGRS 1967) (Fig. 3).

3. In the western part of the Kruja tectonic zone, from the Rodon cape towards Elbasan, another thrusting fault is traced. It cuts diagonally the structural alignments (Fig. 3). Along its faulting plane a vast diapir occurs through which the Kruja orogen overthrusts the southern Adriatic basin (Fig. 14) thus favoring the possibility of locating the carbonate and flysch structures of interest for hydrocarbon exploration (Velaj, 1989, Miljush, 1973).

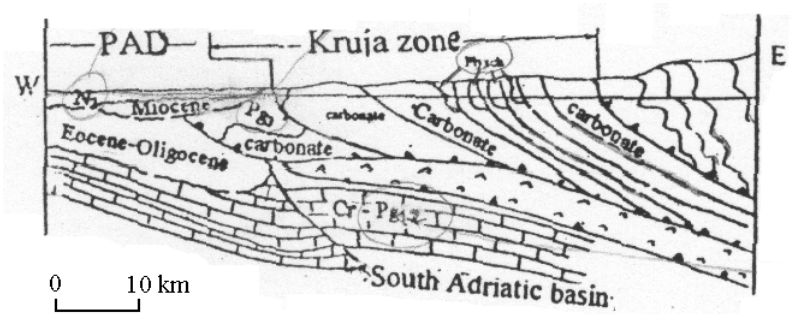

FIG. 10. Schematic geological cross-section through the Kruja zone b. Evaporitic diapirs which have erupted through local faults of the individual structures of the Kurveleshi anticlinal belt (Middle Ionian zone) such as Delvina's, Bashaj's, Ftera's diapirs etc. (Fig. 3). These eruptions have helped the $8-10 \mathrm{~km}$ overthrusting of these structural units and the concealment of the subsurface structure .It must be mentioned that the backthrusting is also affected by the diapir action (Fig. 8).

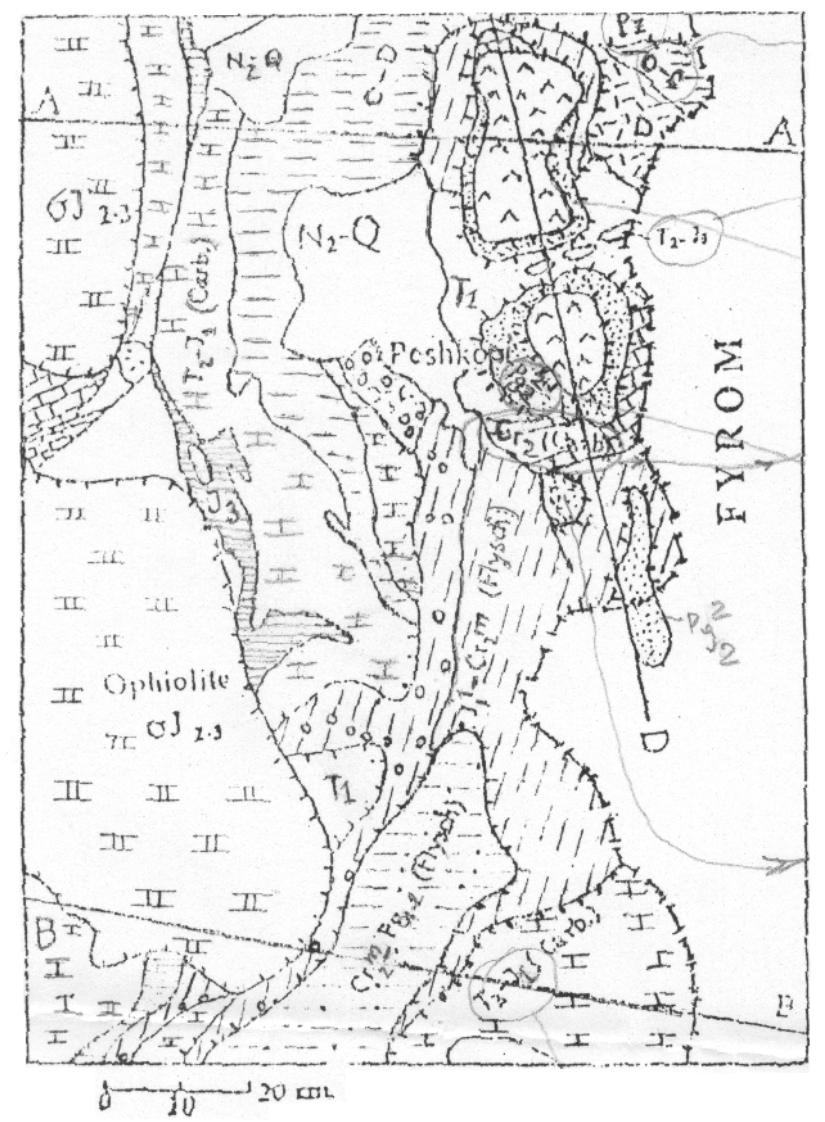

FIG. 11. Tectonic map of the Peshkopia region 
c. Evaporitic diapirs which have erupted nearly vertically in the centre of the carbonate anticlinal structures such as Nevarica's, Jonicati's, Kardhiqi's, Xara - Mursi diapirs. These diapirs generally have a cupola form (Figs. 3, 8) where prospective tectonically screened traps might occur.

\section{THE SEISMIC AND GRAVITY DATA OF EVAPORITE DIAPIRS}

According to the seismic data it is noted that the evaporites of different diapirs like those in Dumrea, Kardhiq, Delvina, Xara etc. are not autochthonous. The presence of many reflections under evaporite diapirs (Fig. 5) indicates that they have overthrusted from East to West. The evaporite deposits are tracked by "free" reflections on the seismic data. Only the top and the basement of the evaporite diapirs are tracked by strong seismic horizons.

An estimation of the velocities in the deep wells shows high values for the evaporite sections (5000$5500 \mathrm{~m} / \mathrm{sec}$ ). Meanwhile, the flysch velocity around the evaporites is in the range of $3500-4500 \mathrm{~m} / \mathrm{sec}$. This velocity difference causes a velocity effect in the seismic image and consequently pitfalls in the interpretation. These difficulties are frequent in those areas and might be overcome by calculation and consideration of the velocity for each seismic horizon (the "layer cake" method).
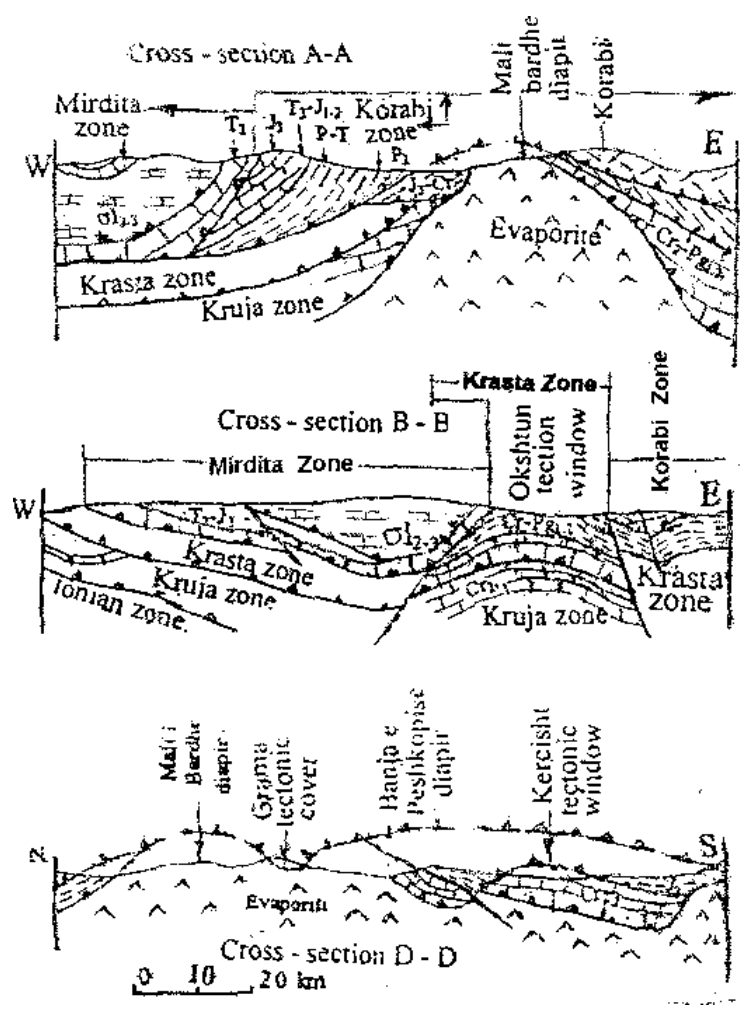

FIG. 12. Schematic geological cross-section in the Peshkopi region

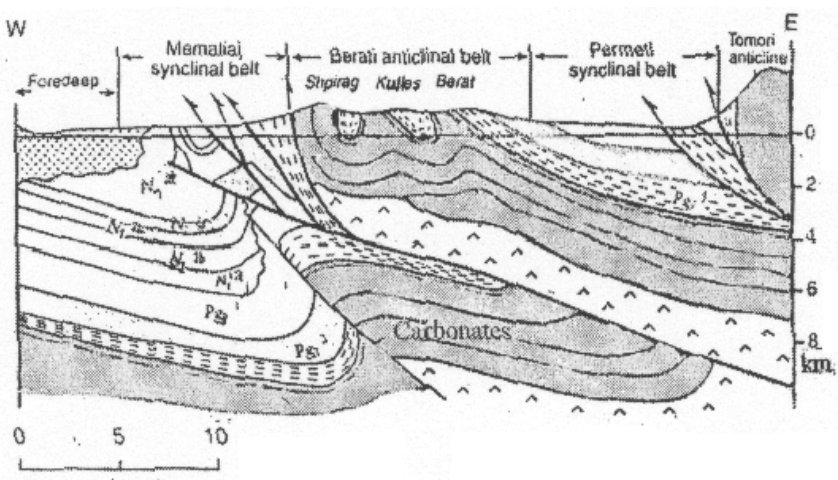

FIG. 13. Schematic geological cross-section through the Berati belt

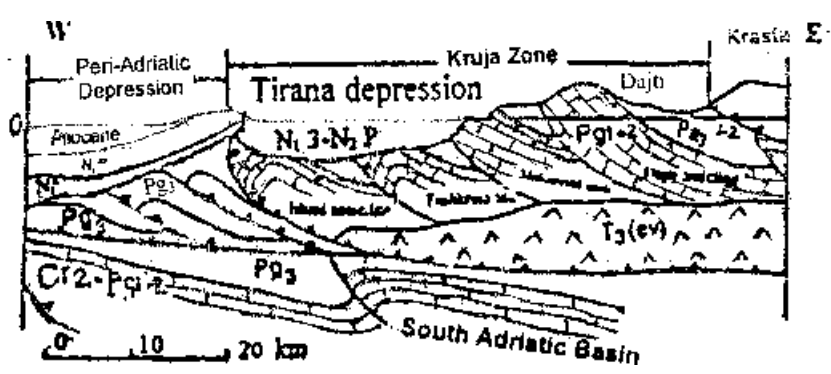

FIG. 14. Schematic geological cross-section through Kruja, Krasta zones and PAD

The average density of the evaporite deposits in the different regions is as follows: Dumre $2.55 \mathrm{~g} / \mathrm{cm}^{3}$, Delvina 2,58 g/cm 3 , Picar-Kardhiq 2,58 g/ $\mathrm{cm}^{3}$, Xara $2.59 \mathrm{~g} / \mathrm{cm}^{3}$ and Peshkopi $2,49 \mathrm{~g} / \mathrm{cm}^{3}$.

The density values of the evaporites decrease in the South-North direction from $2,58 \mathrm{~g} / \mathrm{cm}^{3}$ in Xara, Delvina and Picar-Kardhiq regions to $2.55 \mathrm{~g} / \mathrm{cm}^{3}$ in Dumrea region (Fig. 3). The density of evaporites in Peshkopi region amounts to $2.49 \mathrm{~g} / \mathrm{cm}^{3}$.

The evaporite deposits contact on the surface with two formations: carbonates (Xara, Delvine, PicarKardhiq) and flysch (Dumre, Peshkopi). The evaporites that contact with carbonates $\left(2,67 \mathrm{~g} / \mathrm{cm}^{3}\right)$ are tracked by negative Bouguer gravity anomaly due to their smaller density $\left(2,58-2.59 \mathrm{~g} / \mathrm{cm}^{3}\right)$.

When the evaporites contact with flysch $\left(2,47 \mathrm{~g} / \mathrm{cm}^{3}\right)$ and molasses of Miocene-Pliocene $\left(2,3-2.4 \mathrm{~g} / \mathrm{cm}^{3}\right)$, such as in the Dumre region they are tracked by positive anomaly.

The evaporites of the Peshkopi are not tracked by the Bouguer anomaly. This can be explained by the supposition that the evaporite thickness in depth ought to be relatively smaller. Nevertheless, it must be noted that the Bouguer map of the Peshkopi is not so detailed as are other regions of the Albanides and therefore this interpretation has be to considered with some reserve. 


\section{MAIN FEATURES OF THE DIAPIRISM AND ITS INFLUENCE ON THE OVERTHRUSTING PROCESSES}

The External Albanides resulted from the orogenetic activity over which the evaporites impact is evident. Their interplay is very significant.

The evaporites mechanism of action has been different through different periods of the geological development depending on the intensity of the tectonic forces, pressure, extension etc.

During the rifting stage (from Upper Triassic to Upper Jurassic - Lower Cretaceous) the Ionian and Kruja space was divided into blocks of horsts and grabens by extension normal and strike-slip faults. This is reflected by a change in thickness of the depositional strata. At this stage, the evaporites developed according to the gravitational principle with vertical movement at the depressive and tectonically weak loops (Fig. 15). The evaporite model has a cupola form.

Based on international experience, it is accepted that the evaporites movement is created where the thickness of the overlain strata is over $1000 \mathrm{~m}$ and the evaporites thickens is over $300 \mathrm{~m}$.

Such conditions have been established since early Toarcian causing the evaporites to move toward sectors with lower lithostatic pressure (to horst blocks) and to weak tectonic loops (the intersection of the listric faults).

Consequently, thick reef sediments in the horsts and transgressive carbonate series at the graben zones were deposited (Fig. 16). The evaporites moved during that time from the graben to the horst sectors. By the beginning of Titonian-Neocomian the rifting stage finished and the compression stage with new diapirism features started.

During the collisional stage (Upper Jurassic-Lower Cretaceous to Serravalian) the Ionian zone formation took place under the influence of tangential forces resulting from the lithospheric plate movement as well as from the evaporites contribution. For the Kruja zone the collision time is up to Upper Oligocene.

As a result of the tangential forces, the gradual folding happened and the structures increased their dimensions continuously. Under these conditions, the lithostatic pressures applied to the evaporites were different in different locations. In addition, by the early collision time, the extension normal faults were reactivated as thrust faults (Fig. 17). New tectonic features appeared in the western flanks of the structures. In the meantime, the evaporites were not in equilibrium and started moving toward lower pressure sectors, which, in general, were the top of the structures. The complication of the structures and structural belts and zones happened and evaporites erupted through the fault planes (Fig. 17). This happened simultaneously with the thrusting process. During the post collision stage, which lasted from Serravalian to Pliocene, the overthrusting of the Ionian zone onto the Apulia platform continued (Fig. 17).

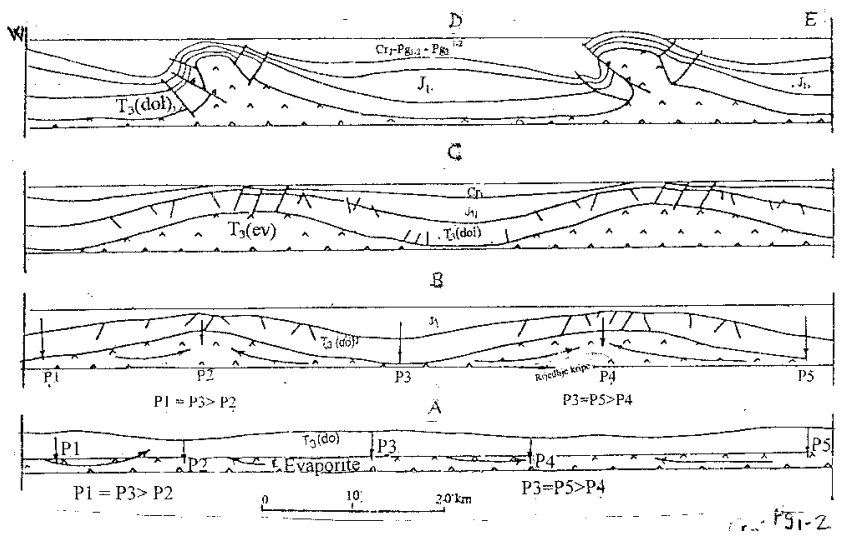

FIG. 15. Tectonic evolution the rifting stage and first phase of the compression

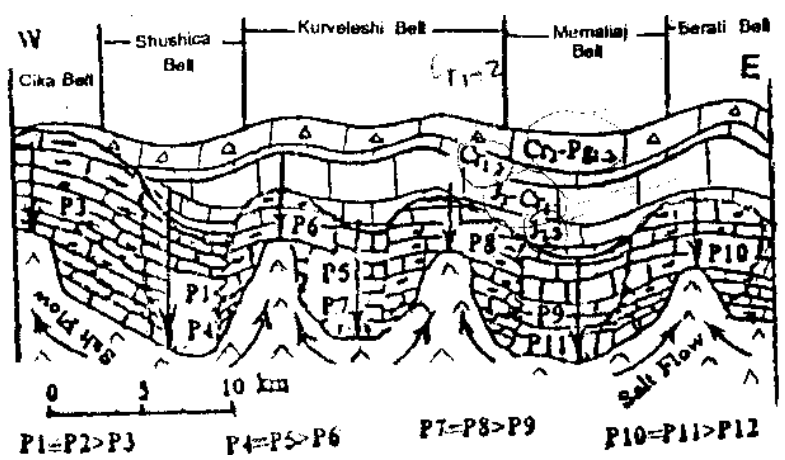

FIG. 16. Schematic profile for the extension of the carbonate formation and the evaporites tectonic development in the Ionian zone

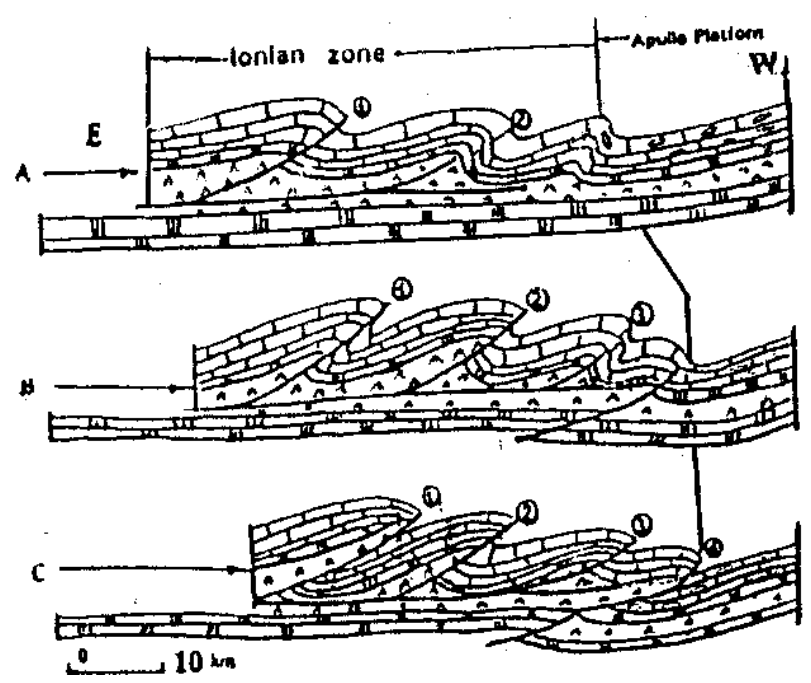

FIG. 17. Scheme of the forming mechanism of the fold and tectonic faults in the Ionian zone 
A further modification of the tectonics took place, mainly through increasing the westward vergeance of the existing structures. In this case, both local and regional thrusts developed. They involved not only the old collision faults but also new faults in the flysch deposits as well (Velaj, 1985, 1989).

These faults served as piercing routes for the evaporites (Fig. 4).

As a result of the complex action of all the above tectonic factors, the Ionian and Kruja sedimentary series overthrust considerably westward even on the Apulia Platform and on the south Adriatic basin.

\section{CONCLUSION}

The upper Triassic evaporites may be encountered in three tectonic settings.

1. Evaporite diapirs that have erupted across or via regional fault planes associated by a marked overthrust with a westward direction.

a. In the western front of the Berati anticlinal belt a regional overthrusting fault of $20-30 \mathrm{~km}$ magnitude can be traced. This overthrust occurs because of the presence of a large diapir sheet which outcrops in Dumrea and Glina-Zavrohon. There are sufficient data showing that some carbonate structures occur beneath this overthrusting fault.

b. In the western front of the Çika anticlinal belt a regional overthrusting fault exists. The orogen overthrusts through this fault and its diapiric body to the Apulian Platform 50-100 km thus hiding a zone of interest.

c. The Kruja tectonic zone has another thrust fault in its western front part as well with perspective interplay of the Southern Adriatic basin and is also associated with the diapir sheet.

2. Evaporite diapirs which have erupted via local faults of the individual structures of the Kurveleshi anticlinal belt. The thrusting magnitude of these diapir sheets is of $8010 \mathrm{~km}$ thus allowing concealment of structural units.

3. Evaporite diapirs which have erupted nearly vertically in the centre of the carbonate anticline structures.

In the internal zones the evaporites appear in tectonic windows of a cupola shape (e.g. Korabi zone, Albania and Redek Macedonia). In this case they are in contact with Kruja Oligocene flysch and Upper Cenomanian rudist carbonate. This led to the suggestion that the Korabi evaporites belong to the Kruja zone thereby showing a global allochthony of the internal zones with continuing External zones underneath.

\section{REFERENCES}

Bornovas, I. and Rondogiani-Tsiambaou, Th., 1983. Geological map of Greece second edition, Athens.

Dragasevic, T., 1983. Oil geologic exploration in the Montenegro offshore in Yugoslavia. Nafta, 34, 397-404

IFP - IGRS 1969, 1967. Etude geologique de l'Epire. (Grecee nord occidentale) Paris.

Jenkins, D. L., 1972. Structural development of western Greece: The American Associations of Petroleum Geologist Bulletin, 56, No. 1, 148-159.

Marco, P., 1975. An outline of Italian Geology AGIP Milano Italy, Tripoli.

Martinis, B., and Pieri, M., 1963. Alcune notizie sulla formazione evaporitica del Triassico Meridionale: Mem. Soc. Geol Bologna. IV, 648-678.

Melo, V., Aliaj, Sh., Kodra, A., Xhomo, A., Lulo, P., Gjata, K. and Hoxha, V. 1991. Tectonic windows of the outer zones in the eastern regions of Albaniades: Gological Sciences Buletin, 2430, (In Albanian)

Miljush, P., 1973. Geologic tectonic structure and evolution of outer Dinarides and Adriatic area: American Assoc. Petrol. Geolog. Bulletin, 57, No. 5.

Muhameti, P., and Pejo, I., 1974. The age of evaporite deposits of Ionian zone: Geological Bulletin, No. 3, 193-231 (in Albanian)

Velaj, T., 1995. The effect of the evaporites tectonic structural model of the Berati anticlinal Belt: Conference "Current and future problems of oil industry in Albania", Tirana, March 31, 1995, Special edition, 146-160

Velaj, T., 1985. Evaporit tectonic role in determination of the Ionian tectonic zone physionomy: Oil an Gas Bulletin, 17-38, (In Albanian)

Velaj, T., 1989. About the style and tectogenesis of External Albanides: Oil and Gas Journal, No. 1, 2, 3-19 and 4-20, (In Albanian)

Velaj, T., Premti, I., Bandilli, L. and Bajo, I., 1990. Evaporitic diapirism in Albania and its influence on the thrust tectonic style: Geol. Scien. Bull., 43-50, (In Albanian)

Velaj, T., 1983. Evaporitic diapirism in the Dumrea cupola and its importance for the oil and gas exploration (Thesis). Tirana

Velaj, T. and Xhufi, C., 1995. The evaporite effect on the tectonic style of the internal Ionian subzone of the Albanides: The 57th EAGE Conference and Technical exhibition, Glasgow, Abst., p. 574

Velaj, T., Xhufi, C. and Jano, K., 1995. The structural model of the Dumrea evaporitic diapir in the Albanides Ionian zone: XV Congress of the Carpathio - Balkan Geological Association, Athens, September 17-20, Abst., p 29. 